\title{
Seedling Growth of Understorey Species of a Southeast Brazilian Tropical Forest
}

\author{
Ivany Ferraz Marques Válio* \\ Departamento de Fisiologia Vegetal; Instituto de Biologia; Universidade Estadual de Campinas; \\ valio@matrix.com.br; C. P. 6109; 13083-970; Campinas - SP - Brazil
}

\begin{abstract}
Thirteen understorey species of a mesophyllous tropical forest were studied under two different photosynthetic photon flux densities (PPFD). Seedlings were grown in the glasshouse under $51 \%$ and $2.6 \%$ solar PPFD. Growth of the seedlings was evaluated by 1-) total height; 2-) leaf number; 3-) leaf dry mass;4-) stem dry mass; 5-) root dry mass; 6-) stem length/mass; 7-)shoot/root mass; 8-) percent allocation to leaf, stem and roots. For most of the parameters recorded, low PPFD drastically reduced growth. It seemed that the strategy of these understorey species was a reduction of growth under low PPFD saving energy for survival.
\end{abstract}

Key words: Seedling growth, understorey species, shade, tropical forest

\section{INTRODUCTION}

In tropical rain forest, many species begin life in deep shade, light being the principal resource that limits the growth of the seedlings. Tree species are often classified into two groups, based on their germination and establishment requirements (Whitmore, 1996). Shade tolerant species can germinate, grow and survive in low light, whereas light-demanding species need a high light environment for germination and seedling establishment. Nevertheless this classification does not embody all the complex ecophysiological known patterns. These two groups seem to be the extremes of a continuum of responses to light (Osunkoya et al., 1994).

Although the term "shade-tolerant" is widely employed, its meaning is not so precise. According to Whitmore (1996), it is possible to distinguish three meanings for ecological purposes, a) shade tolerance can mean the minimum PAR (photosynthetic active radiation) level needed for seedling survival; b) shade tolerance can be related to the length of time for which seedlings can survive at low PAR levels, c) shade tolerance can refer to the amount of PAR required for release from the seedling bank. These meanings are not necessarily independent and although easy to understand they are not always easy to define precisely.

Shading affects plant growth and development at all levels of organization (Grime, 1979; Fetcher et al., 1987; Thompson et al., 1988; Uhl et al., 1988; Woodward, 1990; Popma and Bongers, 1991; Strauss-Debenedetti and Bazzaz, 1991; Chazdon and Kaufmann, 1993; Press et al., 1996). Apart from a group of a few pioneer species (shadeintolerant species), the majority of tropical forest tree species are shade-tolerant species. They are indifferent to gaps and can grow both in a high -

\footnotetext{
* Author for correspondence
} 
and low-light environment. In tropical forests the radiation, which reaches the forest floor under the canopy is only $1-3 \%$ of the total radiation above the canopy (Chazdon, 1988; Clark et al., 1996; Souza, 1996). So, growth rates of seedlings in the understorey are very low. Once the canopy is opened up, a gap is formed and light availability is enhanced increasing growth vigorously. For a successful regeneration growth and survival are the most important. Survival of seedlings in shade varies widely and continuously among tropical tree species, closely reflecting light requirements for regeneration and successional status.

The aim of this paper was to study the effects of light regimes on seedling growth of some native understorey species of a mesophyllous tropical forest in order to understand how these species respond to different levels of irradiance in terms of growth and biomass allocation.

\section{MATERIAL AND METHODS}

Seeds of the species listed in Table 1 were collected from specimens growing under the canopy of a mesophyllous tropical forest (Mata de Santa Genebra, Campinas, SP., $22^{\circ} 49^{\prime} 45^{\prime \prime} \mathrm{S}-47^{\circ}$ 06' 33”W). Seeds were germinated in Petri dishes in incubators at $25^{\circ} \mathrm{C}$ under constant illumination.

$\underline{\text { Table } 1 \text { - Information on the studied species }}$

\begin{tabular}{|c|c|c|c|c|}
\hline Family & Species & $\begin{array}{c}\text { Habit } \\
(\mathbf{m})\end{array}$ & $\begin{array}{c}\text { Seed dry } \\
\text { Mass (mg) } \\
\end{array}$ & $\begin{array}{r}\text { Classes of } \\
\text { dispersal } \\
\end{array}$ \\
\hline Caesalpiniaceae & Bauhinia forficata Link & Tree (5-9) & 73.7 & Ballist \\
\hline Caesalpiniaceae & Holocalyx balansae Micheli & Tree $(15-25)$ & 917.0 & Barochory \\
\hline Celastraceae & Maytenus aquifolium Mart & Shrub (1-2) & 27.2 & Zoochory \\
\hline Euphorbiaceae & $\begin{array}{l}\text { Sebastiania edwalliana } \\
\text { Pax and Hoffm }\end{array}$ & Tree (4-8) & 19.2 & Ballist \\
\hline Lacistemaceae & Lacistema hasslerianum Chodat & Shrub (1-2) & 14.0 & Zoochory \\
\hline Meliaceae & Guarea macrophylla Vahl & Tree $(15-20)$ & 103.0 & Zoochory \\
\hline Meliaceae & Trichilia clausseni C. DC. & Tree $(6-15)$ & 62.6 & Zoochory \\
\hline Meliaceae & T. elegans A. Juss & Shrub (1-2) & 34.0 & Zoochory \\
\hline Meliaceae & T. pallida $\mathrm{Sw}$. & Tree (4-7) & 34.4 & Zoochory \\
\hline Mimosaceae & Acacia polyphyla C DC. & Tree $(15-20)$ & 34.5 & Autochory \\
\hline Rutaceae & Esenbeckia grandiflora Mart. & Tree (4-7) & 21.3 & Ballist \\
\hline Tiliaceae & Luehea divaricata Mart. & Tree $(15-25)$ & 3.8 & Anemochory \\
\hline Violaceae & $\begin{array}{l}\text { Hybanthus atropurpureus } \\
\text { (A.St.Hil.) Taub. }\end{array}$ & Shrub $(0.5-1)$ & 4.4 & Ballist \\
\hline
\end{tabular}

Germinated seeds were transplanted into $0.5 \mathrm{~L}$ plastic pots filled with 2:1 soil of the forest floor plus sand and maintained in a humidifier for acclimatization. Seedlings with one or two leaves (plus cotyledons) were selected for the trials carried on in the glasshouse. One group of plants was placed at random under shade produced by stretching shade cloth over a wooden frame, which reduced the PPFD down to $2.6 \%$ of the solar irradiance without changing the R:FR ratio. The other group was kept close to the first group in the glasshouse but without any cover. Light levels were measured on cloudless day at midday, using a Line quantum sensor LI-191SA attached to a Datalogger LI-1000. The average light level, measured as photosynthetically active radiation (PAR) was $2050 \mu \mathrm{mol} . \mathrm{m}^{-2} \cdot \mathrm{s}^{-1}\left(1045 \mu \mathrm{mol} \cdot \mathrm{m}^{-2} \cdot \mathrm{s}^{-1}\right.$ inside the glasshouse and $54.30 \mu \mathrm{mol} \cdot \mathrm{m}^{-2} \cdot \mathrm{s}^{-1}$ under shade). Temperature in the glasshouse varied from a minimum of $17.9^{\circ} \mathrm{C}$ overnight to a maximum of $30.7^{\circ} \mathrm{C}$ at midday. The duration of the experiments was three months. After the experiment, total shoot length from soil surface to the apical meristem was measured and seedlings were then harvested by splitting open the pots and carefully washing the roots free of soil. Separated 
plant parts (leaves, petioles+stems and roots) were placed in labelled paper bags and dried at $80^{\circ} \mathrm{C}$ for $48 \mathrm{~h}$ and weighed. Three replicates of 20 seeds were also oven dried $\left(80^{\circ} \mathrm{C}\right)$ for $48 \mathrm{~h}$. Plants were watered daily during the experiments, maintaining the soil always moist. Ten plants were used per treatment $(\mathrm{N}=10)$, except for Trichilia clausseni where N=31. Guarea macrophylla and Trichilia pallida, besides in the glasshouse, were also cultivated under the canopy and at the margin of the forest.

Among the species studies nine were trees and four shrubs. Although these species were not very high (Table 1), some of them reached the canopy stratus (Holocalyx, Guarea, Trichilia, Acacia and Luehea).

Table 2 - Effects of light treatments on plant growth. LI= 2.6\% of PPFD; HI= 51\% of PPFD; LI* = under canopy; $\underline{\mathrm{HI}^{*}=\text { forest margin }}$

\begin{tabular}{|c|c|c|c|c|c|c|c|}
\hline Species & Height & Leaf & $\begin{array}{c}\text { Leaf } \\
\text { D.M. } \\
\text { mg }\end{array}$ & $\begin{array}{c}\text { Mean } \\
\text { Leaf } \\
\text { D.M. } \\
\text { mg } \\
\end{array}$ & $\begin{array}{c}\text { D.M. } \\
\text { mg }\end{array}$ & $\begin{array}{c}\text { D.M. } \\
\text { mg }\end{array}$ & $\begin{array}{c}\text { D.M. } \\
\text { mg }\end{array}$ \\
\hline B. forficata- $L I$ & $24.0 \mathrm{a}$ & $9.1 \mathrm{a}$ & $590.1 \mathrm{a}$ & $67.3 \mathrm{a}$ & $309.5 a$ & $329.9 a$ & $1298.5 \mathrm{a}$ \\
\hline B. forficata-HI & $17.7 b$ & $8.2 \mathrm{a}$ & $576.2 \mathrm{a}$ & $69.5 \mathrm{a}$ & $525.6 \mathrm{a}$ & $1387.2 b$ & $2489.1 b$ \\
\hline H. balansae-LI & $14.7 \mathrm{a}$ & $11.2 \mathrm{a}$ & $301.3 \mathrm{a}$ & $26.0 \mathrm{a}$ & $122.5 \mathrm{a}$ & $169.3 \mathrm{a}$ & $593.7 \mathrm{a}$ \\
\hline H. balansae-HI & $11.5 \mathrm{~b}$ & $9.4 \mathrm{~b}$ & $320.1 \mathrm{a}$ & $34.4 \mathrm{~b}$ & $175.6 \mathrm{~b}$ & $414.9 b$ & $910.6 b$ \\
\hline M. aquifolium-LI & $5.1 \mathrm{a}$ & $4.9 \mathrm{a}$ & $15.3 \mathrm{a}$ & $3.0 \mathrm{a}$ & $5.8 \mathrm{a}$ & $5.4 \mathrm{a}$ & $26.3 \mathrm{a}$ \\
\hline M. aquifolium-HI & $5.8 \mathrm{a}$ & $6.1 \mathrm{~b}$ & $91.2 b$ & $15.7 b$ & $25.9 b$ & $39.5 b$ & $156.5 b$ \\
\hline S. edwalliana-LI & $9.7 \mathrm{a}$ & $3.8 \mathrm{a}$ & $63.0 \mathrm{a}$ & $17.0 \mathrm{a}$ & $20.2 \mathrm{a}$ & $16.8 \mathrm{a}$ & $100.0 \mathrm{a}$ \\
\hline S. edwalliana-HI & $24.9 \mathrm{~b}$ & $11.5 b$ & $991.7 b$ & $85.4 b$ & $624.4 b$ & $974.8 b$ & $2592.9 b$ \\
\hline L. hasslerianum-LI & $6.5 \mathrm{a}$ & $6.0 \mathrm{a}$ & $60.4 \mathrm{a}$ & $10.0 \mathrm{a}$ & $19.2 \mathrm{a}$ & $20.4 \mathrm{a}$ & $100.1 \mathrm{a}$ \\
\hline L. hasslerianum-HI & $17.1 \mathrm{~b}$ & $10.6 \mathrm{~b}$ & $476.4 b$ & $44.7 b$ & $151.1 \mathrm{~b}$ & $376.8 b$ & $1004.4 b$ \\
\hline G. macrophylla-LI* & $7.6 \mathrm{a}$ & $3.0 \mathrm{a}$ & $55.7 \mathrm{a}$ & $18.3 \mathrm{a}$ & $31.7 \mathrm{a}$ & $38.5 \mathrm{a}$ & $125.8 \mathrm{a}$ \\
\hline G. macrophylla-HI* & $12.3 b$ & $7.0 \mathrm{~b}$ & $302.6 b$ & $42.8 b$ & $206.7 b$ & $530.7 b$ & $1039.4 b$ \\
\hline G. macrophylla-LI & $12.3 \mathrm{a}$ & $6.3 \mathrm{a}$ & $214.8 \mathrm{a}$ & $33.8 \mathrm{a}$ & $64.5 \mathrm{a}$ & $94.6 \mathrm{a}$ & $373.9 \mathrm{a}$ \\
\hline G. macrophylla-HI & $11.7 \mathrm{a}$ & $7.2 b$ & $476.5 b$ & $66.3 b$ & $274.7 b$ & $744.5 b$ & $1495.7 b$ \\
\hline T. clausseni-LI & $5.6 \mathrm{a}$ & $5.5 \mathrm{a}$ & $43.0 \mathrm{a}$ & $7.8 \mathrm{a}$ & $12.6 \mathrm{a}$ & $13.1 \mathrm{a}$ & $68.7 \mathrm{a}$ \\
\hline T. clausseni-HI & $7.7 \mathrm{a}$ & $5.7 \mathrm{a}$ & $85.1 \mathrm{~b}$ & $14.8 \mathrm{~b}$ & $39.4 b$ & $48.4 \mathrm{~b}$ & $172.9 b$ \\
\hline T. elegans-LI & $11.2 \mathrm{a}$ & $7.7 \mathrm{a}$ & $147.2 \mathrm{a}$ & $18.9 \mathrm{a}$ & $49.0 \mathrm{a}$ & $37.2 \mathrm{a}$ & $234.1 \mathrm{a}$ \\
\hline T. elegans-HI & $17.1 \mathrm{~b}$ & $9.1 \mathrm{~b}$ & $651.1 \mathrm{~b}$ & $64.8 b$ & $200.0 \mathrm{~b}$ & $414.5 b$ & $1265.6 b$ \\
\hline T. pallida-LI & $7.5 \mathrm{a}$ & $6.9 \mathrm{a}$ & $127.4 \mathrm{a}$ & $18.4 \mathrm{a}$ & $40.7 \mathrm{a}$ & $57.7 \mathrm{a}$ & $225.9 \mathrm{a}$ \\
\hline T. pallida-HI & $6.6 \mathrm{a}$ & $6.0 \mathrm{a}$ & $104.0 \mathrm{~b}$ & $20.2 \mathrm{a}$ & $64.0 \mathrm{~b}$ & $142.0 \mathrm{~b}$ & $310.2 b$ \\
\hline T. pallida-LI* & $5.9 \mathrm{a}$ & $5.3 \mathrm{a}$ & $36.7 \mathrm{a}$ & $7.0 \mathrm{a}$ & $15.0 \mathrm{a}$ & $13.3 \mathrm{a}$ & $65.0 \mathrm{a}$ \\
\hline T. pallida-HI* & $7.8 \mathrm{~b}$ & $7.0 \mathrm{~b}$ & $100.7 b$ & $14.2 \mathrm{~b}$ & $63.1 \mathrm{~b}$ & $113.4 b$ & $277.2 b$ \\
\hline A. polyphylla-LI & $12.6 \mathrm{a}$ & $8.9 \mathrm{a}$ & $70.0 \mathrm{a}$ & $8.7 \mathrm{a}$ & $36.6 \mathrm{a}$ & $22.1 \mathrm{a}$ & $128.7 \mathrm{a}$ \\
\hline A. polyphylla-HI & $12.7 \mathrm{a}$ & $3.2 b$ & $130.9 b$ & $38.3 b$ & $95.0 \mathrm{~b}$ & $121.0 \mathrm{~b}$ & $346.9 b$ \\
\hline E. grandiflora-LI & $4.5 \mathrm{a}$ & $4.0 \mathrm{a}$ & $130.3 \mathrm{a}$ & $32.0 \mathrm{a}$ & $26.0 \mathrm{a}$ & $70.3 \mathrm{a}$ & $226.7 \mathrm{a}$ \\
\hline E. grandiflora-HI & $7.3 b$ & $5.0 \mathrm{~b}$ & $526.7 \mathrm{~b}$ & $105.3 b$ & $126.0 \mathrm{~b}$ & $542.0 \mathrm{~b}$ & $1194.7 b$ \\
\hline L. divaricata-LI & $5.7 \mathrm{a}$ & $7.7 \mathrm{a}$ & $28.0 \mathrm{a}$ & $3.6 \mathrm{a}$ & $8.7 \mathrm{a}$ & $6.7 \mathrm{a}$ & $44.3 \mathrm{a}$ \\
\hline L. divaricata-HI & $13.1 \mathrm{~b}$ & $11.0 \mathrm{~b}$ & $576.5 b$ & $52.4 \mathrm{~b}$ & $285.5 b$ & $1212.5 b$ & $2074.5 b$ \\
\hline H. atropurpurus-LI & $13.0 \mathrm{a}$ & $13.3 \mathrm{a}$ & $169.2 \mathrm{a}$ & $12.5 \mathrm{a}$ & $50.8 \mathrm{a}$ & $35.9 \mathrm{a}$ & $255.9 \mathrm{a}$ \\
\hline H. atropurpurus-HI & $20.7 b$ & $14.4 \mathrm{~b}$ & $322.8 b$ & $22.5 b$ & $197.0 \mathrm{~b}$ & $321.9 \mathrm{~b}$ & $841.7 \mathrm{~b}$ \\
\hline
\end{tabular}

Means followed by different letters are significantly different at $5 \%$ level for each species. 
Table 3 - Effects of light treatments on growth responses. LI= 2.6\% of PPFD; HI= 51\% of PPDF; LI*= under canopy; HI* = forest margin.

\begin{tabular}{|c|c|c|c|c|c|c|}
\hline \multirow[t]{2}{*}{ Species } & \multirow{2}{*}{$\begin{array}{c}\text { Shoot/Root } \\
\text { mg mg }\end{array}$} & \multirow{2}{*}{$\begin{array}{c}\text { Stem D.M./Length } \\
\mathrm{mg} \mathrm{cm}^{-1} \\
\end{array}$} & \multicolumn{3}{|c|}{ Biomass allocation (\%) } & \multirow{2}{*}{$\begin{array}{c}\text { RGR } \\
{\text { mg } \mathrm{g}^{-1} \mathrm{~d}^{-1}}\end{array}$} \\
\hline & & & Leaves & Stems & Roots & \\
\hline B. forficata-LI & $2.9^{\mathrm{a}}$ & $12.9 \mathrm{a}$ & $51 \mathrm{a}$ & $24 \mathrm{a}$ & $25 \mathrm{a}$ & $31.8^{\mathrm{a}}$ \\
\hline B. forficata-HI & $0.8 b$ & $29.6 b$ & $23 b$ & $21 \mathrm{a}$ & $56 b$ & $39.1 b$ \\
\hline H. balansae-LI & $2.5^{\mathrm{a}}$ & $8.3 \mathrm{a}$ & $51 \mathrm{a}$ & $21 \mathrm{a}$ & $28 \mathrm{a}$ & - \\
\hline H. balansae-HI & $1.2 \mathrm{~b}$ & $15.3 b$ & $35 b$ & $19 \mathrm{a}$ & $45 b$ & - \\
\hline M. aquifoliums-LI & $3.9^{\mathrm{a}}$ & $1.1 \mathrm{a}$ & $58 \mathrm{a}$ & $22 \mathrm{a}$ & $20 \mathrm{a}$ & - \\
\hline M. aquifolium-HI & $3.0^{\mathrm{a}}$ & $4.5 \mathrm{~b}$ & $58 \mathrm{a}$ & $16 b$ & $25 \mathrm{a}$ & 19.4 \\
\hline S. edwalliana-LI & $5.0^{\mathrm{a}}$ & $2.1 \mathrm{a}$ & $63 \mathrm{a}$ & $20 \mathrm{a}$ & $17 \mathrm{a}$ & $18.3 \mathrm{a}$ \\
\hline S. edwalliana-HI & $1.7 \mathrm{~b}$ & $25.1 b$ & $38 b$ & $24 \mathrm{a}$ & $37 \mathrm{~b}$ & $54.5 b$ \\
\hline L. hasslerianum-LI & $3.9^{\mathrm{a}}$ & $3.2 \mathrm{a}$ & $60 \mathrm{a}$ & $19 \mathrm{a}$ & $20 \mathrm{a}$ & $21.8 \mathrm{a}$ \\
\hline L. hasslerianum-HI & $1.7 \mathrm{~b}$ & $8.8 \mathrm{~b}$ & $47 b$ & $15 \mathrm{a}$ & $37 b$ & $47.5 b$ \\
\hline G. macrophylla-LI & $2.9^{\mathrm{a}}$ & $5.2 \mathrm{a}$ & $44 \mathrm{a}$ & $25 \mathrm{a}$ & $31 \mathrm{a}$ & $14.3 \mathrm{a}$ \\
\hline G. macrophylla-HI & $1.0 \mathrm{~b}$ & $23.5 b$ & $29 b$ & $20 \mathrm{~b}$ & $51 b$ & $29.7 b$ \\
\hline G. macrophylla-LI* & $2.3^{\mathrm{a}}$ & $4.2 \mathrm{a}$ & $57 \mathrm{a}$ & $17 \mathrm{a}$ & $25 \mathrm{a}$ & $2.2 \mathrm{a}$ \\
\hline G. macrophylla-HI* & $1.0 \mathrm{~b}$ & $16.8 b$ & $32 b$ & $18 \mathrm{a}$ & $50 \mathrm{~b}$ & $25.7 b$ \\
\hline T. clausseni-LI & $4.2^{\mathrm{a}}$ & $2.2 \mathrm{a}$ & $62 \mathrm{a}$ & $18 \mathrm{a}$ & $19 \mathrm{a}$ & $1.0 \mathrm{a}$ \\
\hline T. clausseni-HI & $2.6 \mathrm{~b}$ & $5.5 b$ & $51 \mathrm{a}$ & $17 \mathrm{a}$ & $32 b$ & $11.3 b$ \\
\hline T. elegans-LI & $5.2^{\mathrm{a}}$ & $4.3 \mathrm{a}$ & $63 \mathrm{a}$ & $21 \mathrm{a}$ & $16 \mathrm{a}$ & $21.4 \mathrm{a}$ \\
\hline T. elegans-HI & $2.0 \mathrm{~b}$ & $11.7 \mathrm{~b}$ & $51 \mathrm{a}$ & $16 b$ & $33 b$ & $40.2 b$ \\
\hline T. pallida-LI & $2.9^{\mathrm{a}}$ & $5.4 \mathrm{a}$ & $56 \mathrm{a}$ & $18 \mathrm{a}$ & $25 \mathrm{a}$ & $20.9 a$ \\
\hline T. pallida-HI & $1.2 b$ & $9.7 b$ & $33 b$ & $21 \mathrm{a}$ & $46 b$ & $24.4 \mathrm{a}$ \\
\hline T. pallida-LI* & $3.9^{\mathrm{a}}$ & $2.5 \mathrm{a}$ & $56 a$ & $23 \mathrm{a}$ & $20 \mathrm{a}$ & $7.1 \mathrm{a}$ \\
\hline T. pallida-HI* & $1.4 \mathrm{~b}$ & $8.2 b$ & $36 b$ & $23 a$ & $41 b$ & $23.2 b$ \\
\hline A. polyphylla-LI & $4.8^{\mathrm{a}}$ & $2.9 \mathrm{a}$ & $54 \mathrm{a}$ & $28 \mathrm{a}$ & $17 \mathrm{a}$ & $14.6 \mathrm{a}$ \\
\hline A. polyphylla-HI & $1.9 \mathrm{~b}$ & $7.4 \mathrm{~b}$ & $38 b$ & $27 \mathrm{a}$ & $35 b$ & $25.6 \mathrm{~b}$ \\
\hline E. grandiflora-LI & $2.2^{\mathrm{a}}$ & $5.8 \mathrm{a}$ & $57 \mathrm{a}$ & $11 \mathrm{a}$ & $31 \mathrm{a}$ & $26.3 \mathrm{a}$ \\
\hline E. grandiflora-HI & $1.2 b$ & $17.2 \mathrm{~b}$ & $44 \mathrm{~b}$ & $10 \mathrm{a}$ & $45 b$ & $44.7 \mathrm{~b}$ \\
\hline L. divaricata-LI & $5.5^{\mathrm{a}}$ & $1.5 \mathrm{a}$ & $63 \mathrm{a}$ & $19 \mathrm{a}$ & $15 \mathrm{a}$ & $27.3 \mathrm{a}$ \\
\hline L. divaricata-HI & $0.7 b$ & $21.8 \mathrm{~b}$ & $28 b$ & $14 \mathrm{~b}$ & $58 b$ & $70.0 \mathrm{~b}$ \\
\hline H. atropurpureus-LI & $6.1^{\mathrm{a}}$ & $3.9 \mathrm{a}$ & $66 \mathrm{a}$ & $20 \mathrm{a}$ & $14 \mathrm{a}$ & $46.8 \mathrm{a}$ \\
\hline H. atropurpureus-HI & $1.6 \mathrm{~b}$ & $9.5 b$ & $38 \mathrm{~b}$ & $23 \mathrm{a}$ & $38 b$ & $58.4 \mathrm{~b}$ \\
\hline
\end{tabular}

RGR = relative growth rate

Means followed by different letters are significantly different at $5 \%$ level for each species.

At the end of the experiment, growth was evaluated by 1-) plant height; 2-) total number of leaves; 3-) leaf dry mass; 4-) stem dry mass; 5-) root dry mass. Then the following were calculated: 1-) mean leaf dry mass (total leaf dry mass/number of leaves); 2-) relative dry mass allocation to leaves, stems and roots; 3-) allocation of dry mass between shoot/roots; 4-) stem robustness as total mass/length $\left(\mathrm{mg}^{-\mathrm{cm}^{-1}}\right)$ and 5-) relative growth rate $\left(\mathrm{mg} \cdot \mathrm{g}^{-1} \mathrm{~d}^{-1}\right)$, according to
Hunt (1982). Significant differences between the two light treatments for each species was calculated by comparison of means of two small samples according to the modified form of Student "t" test at 5\% level (Bailey, 1981). 


\section{RESULTS}

All species grew in both treatments, although some species grew more rapidly than others (Table 2).

Seedling height, an indication of individual competitiveness when light became available (King, 1994), was shown to be significantly higher at higher irradiation for 8 out 13 of the species. The total number of leaves, total leaf dry mass or mean leaf dry mass were also enhanced in most species by higher irradiance.

Species differed greatly in relative growth rates. Bauhinia forficata grew most rapidly $(31.8 \mathrm{mg} . \mathrm{g}$ ${ }^{1} \mathrm{~d}^{-1}$ ) while Holocalyx balansae and Maytenus aquifolium presented no growth under low irradiance. At higher irradiance, Luehea divaricata attained the highest growth rate (70mg. $\mathrm{g}^{-1} \mathrm{~d}^{-1}$ ) and Trichilia clausseni the lowest (11.3mg. $\mathrm{g}^{-1} \mathrm{~d}^{-1}$ ). Low irradiance drastically reduced allocation to the roots in all species (Table 3 ). This could be seen as $\%$ of total biomass as well as by the ratio shoot/root. Proportionally most of photosynthates remained in the leaves of the plants growing under low irradiance (Table 3). There was contrast between photosynthate allocation to leaves and roots under low and high irradiance. Allocation to stems was not so conspicuous although the ratio stem dry mass/length was consistently higher for plants growing under higher irradiation.

\section{DISCUSSION}

The species studied are frequently growing under the forest canopy or at shaded places as margins of gaps. Although they were expected to be very tolerant to understorey shade, some variation in growth responses to the shade treatment was likely to occur.

Seeds of all these species have no hard teguments (impermeable to water) and photoblastic behaviour was absent. High percentage of germination were obtained in light or darkness. Besides, seed size seemed to be not relevant to growth and establishment in deep shade. For example, Bauhinia forficata with 8\% of Holocalyx balansae seed dry mass,produced seedlings with the double of total biomass when growing in deep shade. The growth of seedlings measured in deep shade apparently was not related only to the deployment of seed reserves. Seeds of the Meliaceae species seemed to be of the recalcitrant type (Roberts, 1973). Germination was drastically reduced when seeds became dehydrated. So, germination under natural conditions was favoured under the canopy where the conditions of high humidity were most likely to occur.

Qualitatively almost all species responded similarly to the light treatment presenting much higher relative growth rates under high irradiation. Quantitatively, considerable variation in growth rates could be observed under high as well as low irradiances. These differences in RGR at time of gap formation could be very important to the success of an individual later on.

A common feature exhibited by the plants growing under low irradiance was a high allocation of photosynthates to leaves in detriment of roots. It seemed that at low irradiance $(2.6 \%$ of solar PPFD), photosynthesis was reduced to a low level just to suffice the expenditure of respiration leaving very low amounts of energy for growth processes. Higher stem dry mass in plants under higher irradiation reflected carbohydrate storage capacity for future growth, as well as total dry mass which could be correlated with carbon fixation (Table 3).

Extensive research on shade effects has been carried out on reduced light irradiance without a corresponding reduction in R:FR (Whitmore, 1996; Poorter, 1999) as well as with change in spectral quality of light. Several contributions of reduced R:FR on growth responses of seedlings in the understorey are well-documented (Lee et al., 1996).

In this paper seedlings of Guarea macrophylla and Trichilia pallida were grown simultaneously in the glasshouse and in natural conditions under the forest canopy and forest margin (Tables 2 and 3). The PPFD on the forest floor was much lower than that of the glasshouse $\left(<0.5 \%\right.$ or $\left.3-5 \mu \mathrm{mol} . \mathrm{m}^{-2} . \mathrm{s}^{-1}\right)$ and also the R:FR ratio of 0.37 (Souza, 1996).

Although quantitative differences could be observed between seedlings growing under nets in the glasshouse and the forest understorey no morphological alterations were noticed due to influence of low R:FR ratio. Furthermore temperature effects on growth of seedlings in the glasshouse and the forest cannot be disregarded. It is possible that under very low irradiance the seedlings survive only because of very low respiration rates and to temporary sunflecks. Having no available energy for mass increments 
the R:FR effects on development become inoperative. At very low irradiance the low R:FR ratio may be more concerned possibly with induction of seedling dormancy. The R:FR ratio will affect morphological characters of the seedlings only when photosynthesis is no longer a limiting source of energy.

All species tolerate low irradiance $(2.6 \%)$ at least during the time of the experiments. The TCR under low and high irradiance for each species showed differences on the levels of shade tolerance. For example, the TCR under low irradiance was $8.8,53.3$ and $85.6 \%$ of the TCR under height irradiance for Trichlia clausseni, $T$. elegans and T. pallida, respectively, being the last species less affected by shading.

It seems that the strategy of these understorey species is a reduction of growth rates under low irradiance and to divert all its resources on survival until more light becomes available.

\section{ACKNOWLEDGEMENTS}

I would like to thank Fundação J.P. Oliveira for the facilities and support in the Mata de Santa Genebra. I am also indebted to Profs. J. Tamashiro and J. Semir for identification of the botanical material.

\section{RESUMO}

(Crescimento de plântulas de espécies de subbosque de uma floresta tropical do sudeste brasileiro). Respostas de crescimento de plântulas ao sombreamento têm sido objeto de intensa pesquisa em regiões temperadas e florestas tropicais úmidas. Neste trabalho, treze espécies de sub-bosque foram estudadas sob duas diferentes densidades de fluxo de fotons fotossintéticos (PPFD). Plântulas foram mantidas em casa de vegetação sob $51 \%$ e $2,6 \%$ da irradiação solar. O crescimento das plântulas foi avaliado através de: 1-) altura total; 2-) número de folhas; 3-) massa seca das folhas; 4-) massa seca do caule;5-)massa seca da raiz; 6-)razão comprimento do caule /massa seca do caule; 7-) razão da massa seca da parte aérea/raiz; 8-) porcentagem de alocação de fotossintatos para folhas, caule e raiz. Para a maioria dos parâmetros considerados, baixa PPFD reduziu drasticamente o crescimento. É possível que a estratégia dessas espécies de sub-bosque esteja na redução de crescimento sob baixa PPFD, resguardando energia para a sobrevivência.

\section{REFERENCES}

Bailey, N. T. J. (1981), Statistical Methods in Biology. $2^{\text {nd }}$ ed. London : Holder and Stoughton.

Chazdon, R. L. and Kaufmann, S. (1993), Plasticity of leaf anatomy in relation to photosynthetic light acclimation. Funct. Ecol., 7, 385-394.

Fetcher, N. Oberbauer, S. F.; Roja, G. and Strain, B. R. (1987), Efectos del regimen de luz sobre la fotosintesis y el crescimento en plantulas de arboles de un bosque lluvioso tropical de Costa Rica. Rev. Biol. Tropical, 35, 95-110.

Fetcher, N.; Strain, B. R. and Oberbauer, S. F. (1983), Effects of light regime on the growth, leaf morphology and water relations of seedlings of two species of tropical trees. Oecologia, 58, 314-319.

Grime, J. P. (1979), Plant strategies and vegetation process. J.Wiley, N.York, USA.

Hunt, R. (1982), Plant growth curves. The functional approach to growth analysis. Edward Arnold, London.

Kappel, F. and Flore, J. A. (1983), Effects of shade on photosynthesis, specific leaf weight, leaf chlorophyll content, and morphology of young peach trees. J. Am. Soc. of Hort. Sci., 108, 541-544.

King, D. A. (1994), Influence of light level on the growth and morphology of saplings in a Panamanian forest. Am. J. of Bot., 81, 948-957.

Lee, D. W.; Baskaran, K.; Mansor, M. and Mohamed, H. S. K. (1996), Irradiance and spectral quality affect Asian tropical forest tree. Ecology, 77, 568-580.

Poorter, L. (1999), Growth responses of 15 rain-forest tree species to a light gradient: the relative importance of morphological and physiological traits. Funct. Ecology, 13, 396-410.

Popma, J. and Bongers, F. (1991), Acclimation of three Mexican tropical rain forest tree species to a change in light availability. J. of Tropical Ecology, 7, 85-97.

Press, M. C.; Brown, N. D.; Barker, M. G. and Zipperlen, S. W. (1996), Photosynthetic responses to light in tropical rain forest tree seedlings. In: Swaine, M. D. (ed.). Ecology of Tropical Forest Tree Seedlings, UNESCO/Parthenon, Paris/Carnforth. pp. 41-58.

Ramos, J. and Grace, L. (1990), The effects of shade on the gas exchange of seedlings of four tropical trees from Mexico. Funct. Ecology, 4, p.667-677.

Riddoch, I.; Lehto, T. and Grace, J. (1991), Photosynthesis of tropical tree seedlings in relation to light and nutrient supply. New Phytologist 119, p.137-147. 
Roberts, E. H. (1973), Predicting the storage life of seeds. Seed Sci. and Tech., 1, 499-519.

Souza, R. P. (1996), Germinação, crescimento, atividade fotossintética e translocação de compostos de carbono em espécies arbóreas tropicais: estudo comparativo e influência de sombreamento natural. Tese de Doutorado - Universidade Estadual de Campinas.

Strauss-Debenedetti, S. and Bazzaz, F. A. (1991), Plasticity and acclimation to light in tropical Moraceae of sucessional positions. Oecologia, 87, 377-387.

Thompson, W. A.; Stocker, G. C. and Kriedemann, P. E. (1988), Growth and photosynthetic response to light and nutrients of Flindersia brayleyana $\mathrm{F}$. Muell., a rain forest tree with broad tolerance to sun and shade. Australian J. of Pl. Physiol., 15, 299-315.

Uhl, C.; Clark, K.; Dezzeo, N. and Maquirino, P. (1988), Vegetation dynamics in Amazonian treefall gaps. Ecology, 69, 751-763.

Whitmore, T. C. (1996), A review of some aspects of tropical rain forest seedling ecology with suggestion for further enquiry. In: Swaine, M. D. (ed.). Ecology of Tropical Forest Tree Seedlings, UNESCO/Parthenon, Paris/Carnforth. pp. 3-39.

Woodward, F. I. (1990), From ecosystems to genes: the importance of shade tolerance. Trends in Ecology and Evolution, 5, 111-115.

Received: June 13, 2001; Revised: October 10, 2002; Accepted: July 17, 2003 